\section{TRAUMA, REPRESSED MEMORY, AND THE QUESTION OF 'AUTHENTICITY': READING SEE UNDER: LOVE AND BELOVED THROUGH BHABHA}

\section{Phrae Chittiphalangsri ${ }^{1}$}

\begin{abstract}
Trauma and the repressed memory of Jewish Holocaust survivors and AfricanAmerican slaves are issues that require the notion of 'authenticity' in fictional representation. The Zionist discourse demands that Holocaust fictions be written by true witnesses of the genocide and with respectful seriousness, for the Holocaust is a sacred, incomparable phenomenon in Jewish history. In the same manner, the Black American narrative needs authenticity to articulate the Black's own voice, which has been predominately constructed by White Americans since the early history of America. David Grossman's See Under: Love (1999) nevertheless deals with the problem of 'authenticity' in describing the Holocaust, despite the fact that the writer never experienced the Holocaust directly and even wrote it in a postmodern, humorous, and fantastic manner. Likewise, Toni Morrison's Beloved (1987) introduces a new way to write an authentic AfricanAmerican narrative, i.e. magical realism. This essay explores the problem of authenticity by applying Homi K. Bhabha's cultural theory to analyse it in four parts.
\end{abstract}

\footnotetext{
${ }^{1}$ MPhil/PhD student in Comparative Literature at University College London
}

The first part investigates the causes and the culturally specific backgrounds of the Zionist and the American Africanist's views towards 'authenticity' in literary representation. The second part clarifies the argument by situating 'authenticity' in Bhabha's framework of the pedagogical. The third part furthers the argument by detailing the performative use of the fantastic and magical realism to render the effect of liminality. The last part concludes the notion of 'authenticity' by pointing out the supplementary aspect of Bhabha's theory when applied to the two novels.

\section{Introduction: The Problem of 'Authenticity' in Zionist and} American-Africanist Discourses

" $[\mathrm{W}] \mathrm{rite}$ with authenticity, like a genuine writer', [...] Bruno tried his best to be convinced, he really and truly tried to achieve the commonplace despair they prattled about [...]' (Grossman, 1999:138).

'They forgot her like a bad dream. After they made up their tales and decorated them [...] It took longer for those who had spoken to her, lived with her, fallen in love with her, to forget [...] Remembering seems unwise [...] It was not a story to pass on' (Morrison, 1997: 274-75).

Trauma, repressed memory, and the intrusion of the past into the present are central to the creation of David Grossman's See Under: Love (1999) and Toni Morrison's Beloved (1987). Belonging to the genre Gilead Morahg calls the Modern Israeli 'exploratory' fiction category, ${ }^{2} \mathrm{See}$

\footnotetext{
2 Gilead Morahg, in his article 'Breaking Silence: Israel's Fantastic Fiction of the Holocaust' (1997), categorises Modern Israeli Holocaust fictions in two groups according to how the issue of the Holocaust is treated in the
} 
Under: Love explores the impact of the Shoah, or the Holocaust, on the second generation of Jewish survivors in Israel, where, despite the lack of 'first-hand' experience of the Holocaust trauma among its 'new' people, the shame of having been reduced to a subhuman existence in Europe during the Second World War still dominates the formation of both collective and individual Israeli identity. Grossman tells this story of trauma and repressed memory through Shlomo Neuman, son of the Polish-Jewish survivors, who, like others of his own generation, is protected from the painful knowledge of what his parents encountered 'Over There' by their painful silence. Shlomo becomes a writer whose mission is to understand what lies behind the silence of his parents. He turns to the fantastic mode of writing in order to go beyond the taboo by exploring the life of the dead Polish-Jewish writer Bruno Schulz and his grandfather Anshel Wasserman, a surviving children's story writer who comes to live with him for a short period of five months and then disappears.

Similarly, the narrative of Morrison's Beloved centres around the repressed memory of slavery, which leaves an indelible imprint on the body and soul of Black-American characters who still carry on their traumatic experience at a plantation. The sorrow, as Morrison points out, is not an individual's suffering but exists as a collective pain that the Black community tries to repress. Raped,

writings. The first category includes earlier fictions that try to reflect the experience of the Holocaust in a largely descriptive way, e.g., the works of Savyon Liebrecht, Nava Semel, etc. The second category, exemplified by the work of David Grossman, refers to the later works that attempt to explore the Holocaust in a selfconscious manner, rather than simply reflect the actual trauma 'faithfully'. whipped, and robbed of the milk stored in her breasts for her baby, pregnant Sethe escapes from her oppressor, schoolteacher, only to discover that her freedom forces her to commit infanticide in order to save her children from the pain of slavery that she knows only too well. The dead daughter, Beloved, comes back to her eighteen years later in the form of a grown up woman: a 'ghost' of past trauma that becomes magically real in Morrison's narrative. Beloved comes back to Sethe to unlock the door of her repressed memory, placing the traumatic past in the course of the present, and becomes Sethe's externalisation of a life plagued by past dehumanisation. It is precisely the ghostly presence of Beloved, a reminder of the violence of slavery, that drives the Black community away from 124 Bluestone Road, leaving the women in that haunted house with 'baby's venom'.

Trauma and repressed memory work as 'true' experience suffered by characters in both novels. However, on the level of representation in the narrative, trauma and repressed memory in Zionist and American-Africanist ${ }^{3}$ discourses call into question the 'authenticity' of the narrative, asking for the justification of the 'true' account of such experience. The specificity, uniqueness, and undesirability of the Holocaust in Jewish history, and the 'unspeakable', unwritten truth of Black slavery, heighten the discursive demand for the accurate presence of such traumatic testimony. Nevertheless, attention must be paid to the differences between the two

\footnotetext{
3 'American Africanism' is a termed coined and used by Toni Morrison in her critical book Playing in the Dark: Whiteness and the Literary Imagination. The term refers to the discourse in which Black-American personae are racially constructed by White Americans in order to serve the literary hegemony of 'White' America.
} 
discourses' calls for authenticity, as the nature of Jewish and Black-American narrative varies as a result not only of the geographical distance but also of the historio-cultural discrepancies that shape the discourses themselves.

The specific characteristic of Zionist cultural politics lies in its repudiation of inaccurate accounts of the Holocaust. Terrence Des Pres observes that Holocaust fiction, through a somewhat 'undeclared and unproved' customisation, has had certain strict limitations prescribed for it regarding the way it should be perceived. There are three distinctive prescriptions that apply to the situation of Holocaust writing, namely the obligatory treatment of the Holocaust as a unique event which is complete in itself and unconnected with history, the accurate and faithful representation of the Holocaust, and, finally, the requisite 'serious' approach to the sacredness of the Holocaust (Des Pres, 1988: 216-217). These limitations set up a literary taboo of which any violation would count as an abusive, disrespectful act. Such restrictions significantly imply the legitimacy of who has the right to write. Definitely, in order to comply with the prescribed rules, one must have first-hand experience of the Holocaust so that the sacred trauma may be loyally translated into words. In other words, the actual experience and the representation must correspond perfectly with one another to fit the Zionist discourse. Hence the concept of authenticity becomes an indispensable, specific criterion for Jewish Holocaust literature. Should this rule apply, it definitely problematises the representation of the Shoah in Grossman's See Under: Love, in which the Holocaust is told from the perspective of an outsider, an inauthentic voice.
While Zionist discourse calls for the authentic representation of past trauma of the Holocaust, the experience of slavery for Black Americans demands that 'authenticity' be redefined in relation to White Americans so that the 'racialised' Black-American representation can be transposed from a discourse of what Toni Morrison terms 'American Africanism' a White-oriented, and racially constructed discourse - to one that can justify the Africanist presence in American literature as 'authentic' in and of itself. According to Morrison, literature in the United States, especially during the national formative years, was produced as a result of the quest for 'freedom', a cultural hegemony White Americans strove for after their liberation from Britain. (see Morrison, 1992) The need for freedom not only confirmed the new nation's liberation from the old world but was also essential to the stabilisation of national identity. This is precisely the point where African people became 'the other' on the level both of political implementation and of literary representation. Morrison points out that literature by White-American writers reflects this alienation of the Africanist presence so that the young nation's ideology of freedom could be maintained. The Black-American characters are created to be 'the other' of the powerful, civilized, and free White men in order to confirm the American status quo's equality with the European. The Black American is therefore constructed by the White and comes to operate as American Africanism. Morrison is also aware that American Africanism has come to have a 'metaphysical necessity' in the rhetoric of all national struggles. The reference to the Black American, whether in the writing of the constitution or the battle over illiteracy and educational opportunity, is metaphysically necessary in the American consciousness. It can be 
inferred that, along with its surrogate properties in defining 'free' America, American Africanism also needs recognition of its own authenticity in order to resurrect its unwritten past and articulate the 'unspeakable' trauma. Therefore, Black writing should take issue with this loss in history so that American Africanism can be authentically represented, and this is precisely what the author of Beloved seeks to do.

The demand for authenticity in Zionist and American-Africanist discourses, therefore, problematises the representation of past trauma and repressed memory. Furthermore, the texts of See Under: Love and Beloved differ technically and thematically in their treatment of the issue of authenticity. See Under: Love has been accused of breaking the taboo of Jewish Holocaust narrative by allowing an irrelevant voice to intrude on this sacred Kingdom. On the other hand, the text of Beloved demonstrates the possibility of authenticating Black narrative in its attempt to compensate for the silence of the Black voice in American political and literary history. This discrepancy between authentic narratives forms the major point of discussion in this essay. By applying Bhabha's notions of the people's space (the pedagogical and the performative), liminality and supplementarity, this essay focuses on the way in which authenticity emerges through the 'modern' representation of trauma and repressed memory in the two novels.

\section{Situating Authenticity: The Pedagogical Labyrinth}

It is precisely what Bhabha terms 'the pedagogical and the performative', or the autonomous, self-generating historical entity and the signification process of the present, that lay the ground for an analysis of rhetorical authenticity in See Under: Love and Beloved. In The Location of Culture (2003), Bhabha meditates on the lack of a proper label to express the growing confusion of the modern world. He seeks to describe the 'newness' of transnational experiences such as migration, diasporas, and post-colonialism and the underlying systems and utterances that perpetuate modern culture. This exploration of modernity and the production of culture correspond to the narrativisation of Grossman's version of the Holocaust and Morrison's writing of the 'unseen' truth of slavery. It is apparent that the three texts share two corresponding issues: first, the perpetuation of cultural consciousness through the impact of the past on the present and, second, the quest for an 'appropriate' identity in a world that is full of transgression but lacks certainty. In order to decipher these two issues with respect to 'authenticity', one must be aware of the multidimensional nature of authenticity as well. Since the issues of trauma and repressed memory in these two novels exist on the level of both historical reality and fictional representation, the two levels are likely to overlap. Thus, it is essential to distinguish between these two levels of how authenticity operates in the two novels.

Bhabha proposes that the space of the people in the modern era arises as a result of the tension between the pedagogical and the performative. This tension occurs when the pedagogical, an a priori, absolute historical autonomy that designates people as a pedagogical object, and the performative, an enunciatory mediator of the signifying process that enacts the inventive performance of the people, clash and generate an interstitial space in which the people 'are neither the beginning nor 
the end of the national narrative' (Bhabha, 2003:146). The space of the people thus becomes a locus of the 'in-betweenness' of cultural production, where the pedagogical acts as the people's tradition, generating itself through successive moments in history, and the performative seeks to intervene in this pedagogical tradition by differentiating the image of the people as sign from its signification of the sign of the Self through constant, repetitive performance.

The clash between the pedagogical and the performative deconstructs both the unchangeable absoluteness of history and the aimless scheme of the present. History, though signifying impasse and closure, is a realm where the 'pure signifier' of historical entity is undermined by the people's performance, which deconstructs the historical 'pure signifier' into the sign of people's image self, hence perpetuating the alienation of 'otherness' within the people's space. In this way, the pedagogical, together with the enuciatory process of the performative, produce the locus of 'in-betweenness' where 'otherness' is situated within, not outside. Paradoxically, this split in between the people's space is precisely the hypothesis for 'authenticity' in the context of Bhabha's 'Modernity' - Zionist and AmericanAfricanist discourses, which shall be discussed in the following parts.

If the space of the people can be mapped, the pedagogical space probably emerges as a labyrinth in which the paths meander unexpectedly, without definite direction. The pedagogical in the map of See Under: Love's narrative covers the mighty realm of the Holocaust, which reveals certain incompatibilities regarding theoretical implementation. The pedagogical in Bhabha's theorisation emerges as an autonomous historical entity that allows the intervention of the performative, but if the Holocaust in Jewish history is taken as the pedagogical, it is likely that it will disavow any performance that interferes with its sovereignty. This discrepancy, nevertheless, reveals a further complication of pedagogical politics itself, since the Holocaust as the pedagogical tends to mingle deliberately the image and the self and therefore forbids the performative to differentiate between them. Furthermore, this 'peculiarity' of the pedagogical Holocaust seems to claim the perpetuation of the performative by itself. Morahg explains the cause of this specificity by pointing out the prevailing Israeli cultural code which is the major force that informs the discourse of ideological Zionism; that is, the existence of the Holocaust in Jewish history is in itself the 'epitome of everything that Zionism sought to reject' (Morahg, 1997: 149). The desire to dismiss the Holocaust is transformed into the selfimplementation of a new cultural politics in Israel, their 'new home'. That is, unlike the Zionist discourse, the Israeli experience will no longer be, in any way, relevant to the Holocaust. That is why the pedagogical Holocaust attempts, with all its might, to generate a new Israeli identity by, ironically, plunging itself into oblivion in order to produce a totally different performative. In this way, 'authenticity' can still be maintained in that realm of oblivion, known only to those who have dwelled in it.

With this problem of the pedagogical Holocaust in mind, Grossman explores this painful oblivion through the childhood experience of Shlomo in the 'Momik' section of his novel. On the level of historical background, the complicated politics of Zionism is constructed around its own 'absence': the experience of the 
Holocaust is kept silent by the survivors, and remains absent from the next generations, who never experience it. Nevertheless, the absence of the Holocaust in the new Jewish-Israeli community instead fuels the desire to unearth the cause of this enigmatic absence. The more his parents try to lock him away from their past trauma, the more enthusiastic Shlomo becomes in finding the hidden cause that keeps him from knowing it. However, it seems that this politics of oblivion becomes flawed by the overwhelming power of trauma and repressed memory; as Derrida puts it, absence presupposes presence, and therefore in its deferral, presence 'leaks' into absence. Although his parents landed safely and settled down in Jerusalem properly, the Holocaust trauma still leaves an imprint of fear in their new 'normal' life. Shlomo's parents eat their supper with blinding effort, as if it were the last meal for them. Shlomo cannot help but pray to God to help them overcome this battle to survive hunger. And when ' $[\mathrm{t}] \mathrm{he}$ battle is over[, t]hey've earned another day' (Grossman, 1999:49). His father usually screams in terror at night and becomes so paranoid about his 'bloodstained' hands, a result of his service as Sonderkommando ${ }^{4}$ in the concentration camp, that he cannot touch his son. The 'leakage' of the absence of the traumatic past then manifests through the deferred presence of unconscious symptoms of his parents. It also externalises through the 'mad' characters such as Hannah and Grandfather Wasserman. Both Hannah and Wasserman are the evidence of the Nazi's violence that the community seeks to suppress. Hannah,

\footnotetext{
${ }^{4}$ Gilead Morahg explains this term as 'Special Squads' of prisoners who were assigned to remove the bodies from the gas chambers and transfer them to the crematoria. See the note to Morahg (1999).
}

having undergone unspeakable horror in the concentration camp, suffers from hysterical symptoms that make her 'want to mate all the time'. She runs naked through the streets of Jerusalem at night, insulting God for deserting her. Likewise, Shlomo's grandfather, Wasserman can barely communicate with others; he can only talk to himself, telling stories to the imagined 'Herr Neigel', the Nazi officer with whom he stayed briefly during the War. Their loss of contact with reality imbues Shlomo with an eagerness to find the truth of the source of their suffering. In this way, the politics of the pedagogical Holocaust proves incapable of total control of self-repression and falls under the scheme of the difference and deferral of the absence/presence duality.

On the representational level, another pedagogical complication that emphasises the problem of authenticity in See Under: Love lies in the narrativisation of the Holocaust experience. Shlomo, who becomes a writer, comes to realise the difficulty of rendering the surge of the Holocaust that has perturbed him since childhood. He strives to write the story of his grandfather and his experience at the Nazi Death Camp. But Shlomo finds himself trapped in the pedagogical, labyrinthine code of authentic narration of the Jewish Genocide, which demands not only the unity of the self and image of the Holocaust even at the level of representation but also the uniqueness of literary style. Thus Shlomo faces two significant but ironic limitations of authenticity: first, he lacks empirical experience, which renders him an inauthentic voice in telling of the Holocaust, and, second, were he to write about the Holocaust, he would inevitably risk the penalty of literary plagiarism if he copied a writer who had truly witnessed the 
genocide, just as Wasserman was accused of imitating other children's story writers by the critic Schapira. The labyrinth of the pedagogical in See Under: Love proves a paradoxical cultural menace in which its politics force a deliberate oblivion of the painful historical entity but fail to prevent the leakage of its absence; it limits its discourse to those who actually experienced the Holocaust, but at the same time requires monolithic representations from different writers, which harbour plagiarism since they cannot violate the taboo that restricts their writing and must resolve to the same end.

The pedagogical in American-Africanist discourse is identified in relation to the White narrative. American Africanism is employed in White narrative as 'the other' of everything the Whites want to embrace: for instance, Blacks are the embodiment of 'fear', while Whites are those who possess stability, security, and freedom. This differentiation, which alienates Black Americans from the White ideology, becomes internalised in the Black consciousness. Morrison explained the Black's adoption of the Whites' otherness by citing an example of the nineteenthcentury writers of slave narratives who had to 'appear as objective as possible - not to offend the reader by being too angry, or by showing too much outrage' (qtd. in Grewal, 1996:157). The submission of Black writers to the demands of White ideology leads, according to Morrison, to 'silence' and 'oblivion'. They remain a shadow in their own writing, and eventually this causes them to forget what damage has been done to them. The pedagogical for the AmericanAfricanist discourse is therefore written not by Blacks but by Whites, the 'us' whose freedom ironically sets limits to the liberty of its other. It is a labyrinth that Blacks cannot find their way out of since it is constructed by the Whites.

The Black pedagogical set up by White ideology manifests itself in two kinds of indoctrination: slavery and patriarchy. Undoubtedly, slavery is a sign designated as a binary opposition to 'mastery'. Slavery embodies submission, while mastery encapsulates authority. In Beloved, this double is further intensified by the violent treatment of the White masters and the inevitable surrender of the Black slaves. Schoolteacher strongly views Black slaves as mere subhuman existences; he even gives lesson to his nephews on how to categorise Sethe's characteristics as either human or animal, he tries to burn Sixo alive when he is running away together with his brothers and Sethe. The power of the Whites as embodied in schoolteacher signals the fruitless attempts of the slaves to convince him of their humanity. When Sixo cleverly tells schoolteacher that he has killed and eaten a pig from the farm so that he is better fed and can increase his workload, schoolteacher punishes him in order to 'show him that definitions belonged to the definers - not the defined' (Morrison, 1997:190). There is no way for the Blacks to make the Whites believe that they can be as human, gentle, and loving as the Whites.

The more coloredpeople spent their strength trying to convince them how gentle they were, how clever and loving, how human, the more they used themselves up to persuade whites of something Negroes believed could not be questioned, the deeper and more tangled the jungle grew inside (Morrison, 1997:198; italics added). 
The 'jungle' — the inhuman wilderness is not what the Blacks designate for themselves; rather, it is planted by the 'whitefolks'. The pedagogical self of the Blacks is buried underneath the pedagogical image drawn by the Whites. This is precisely an attempt to reduce the American-Africanist presence to a mere signifier, obliterating its signification through the complete control of slavery. However, in the case of women slaves, the obliteration not only dehumanises women slaves as it does their male counterparts but also robs them of the right to motherhood. Sethe's mother and Baby Suggs give away the children conceived through rape by White men because these children are proof of shame and a confirmation of their debased existence. They only mother children born of their Black lovers, as these children are the product of 'human' life, not animalistic violence. Nevertheless, their motherhood is in fact undermined by the slaveholding scheme of property; the Black mother has no right to her children, as they belong to her White master. When schoolteacher and his nephew catch the run-away Sethe, who is pregnant with Denver, they dig a hole in the ground to support her belly while they whip her, so that they will not harm the child - their property. However, Sethe opposes this pedagogical scheme of property by claiming her children as her own. Instead of submitting them to the authority of schoolteacher, she chooses to kill them with her own hands - just as the proprietor would have the same right to destroy his own property. This violation of the pedagogical leads her to suffer the results of her murder of Beloved and detaches her from the Cincinnati Black community, whose inhabitants dare not break the pedagogical code.

\section{The Performative and the Liminality of the Fantastic and Magical Realism}

The labyrinths of the pedagogical in Zionist and American-Africanist discourses exhibit the same attribute: they are an autonomous impasse as well as a self-generating closure. It would take a tremendous effort to penetrate these pedagogical codes if the performative took a straightforward, confrontational method such as writing with an indifferent attitude towards the Holocaust or aggressively denouncing White domination. However, both David Grossman and Toni Morrison have adopted more effective methods; Grossman turns to the use of the fantastic, while Morrison narrates in the mode of magical realism. The use of the fantastic and magical realism in both novels renders what Bhabha terms 'liminality' able to work hand-in-hand with the performative. Liminality is what prevents the pedagogical and the performative from reaching their primordial, absolute states so that they always remain at the point of emerging, constantly engaging in the process of perpetuating the interstitial space 'in between' the two poles. As stated previously, the 'in-between' space allows the 'authenticity' of the second-generation Israeli writer and the Black-American narrative to emerge in Zionist and American-Africanist discourses. It is precisely the use of the fantastic and magical realism that renders authenticity possible by their participation in articulating the liminality of the pedagogical and the performative.

The fantastic in See Under: Love allows the writer to articulate his voice through the performative in order to undermine the pedagogical code and also to maintain the two polarities within the liminal space. 
There are two significant uses of the fantastic which reveal both the effort of pedagogical subversion and the politics of liminality, as well as providing 'clues' to how authenticity emerges through these two functions; first the 'fantastic' resurrection of the Jewish writer Bruno Schulz and, second, the reconstruction of the concentrationary universe through Grandfather Wasserman and his story. Shlomo, as 'the other' to the authentic voice of the 'genuine' Holocaust writers, projects his voice through this creation of the fantasy which is 'directed towards the absent areas of the world, transforming [the desire for 'otherness'] into something 'other' than the familiar' (Jackson, 1981:19). It is exactly this realm that is 'other than the familiar' that allows 'the other', like Shlomo, to experience authenticity.

In the 'Bruno' section, Shlomo seeks the possible performative that would render his work authentic by imagining how Bruno Schulz would have written the conclusion to his unfinished book, The Messiah. Bruno, who was shot dead in Drohobych in 1942, is fantastically able to escape to Danzig before jumping into the sea and possessing a new existence in the oceanic world. Shlomo joins Bruno by imaginatively merging himself with the sea. Through their magical merging in the fluidity and unruliness of the sea, Shlomo learns of Bruno's pain of not being able to become a genuine writer who can claim not to copy someone else. Throughout Bruno's career, he was called 'the Polish Kafka', mainly due to his exploration of the fatherson relationship, or 'the Polish Proust', probably on the basis of his deviant sexual orientation and his fascination with the past (Brown, 1990:224-46). He was hardly recognised for his own literary virtues.
Feeling Bruno's problem as similar to his own, Shlomo gives Bruno a chance to write the unfinished part of The Messiah. This also gives him a chance to learn how Bruno comes to terms with authenticity. Having learnt from the flock of 'salmon' - a metaphor for the Jews - Bruno realises that the salvation of the Jews must come as a result of their own uniqueness and their belief in their own conscience, rather than following a leader who may lead them to catastrophe; just like the salmon, which travel together aimlessly in schools, they are either eaten by sharks or caught by fishermen, but most of them are led to death by their own leader. Bruno then writes the last part of The Messiah under his new philosophy; the caricatured arrival of the Messiah in the form of a donkey makes the people forget their past and pay attention only to their present. Since there is no past, there is no killing, because people can no longer remember their hatred. Bruno also states that there is even no plagiarism, for literature is just an 'ephemeral art'; the real art lies in learning how to live one's life with one's own uniqueness. Even death is operated by an individual, authentic code in his Messianic society, so there is no mass death. This fantastic vision effectively deconstructs the impassability of the pedagogical by subverting its unity of self and image; the signifier and the signification of the Holocaust, which are held strongly as one in the Zionist discourse, become destabilised by the intrusion of the performative fantastic, whose obliteration of the past juxtaposes with a pedagogical attachment to the past, causing a 'split' in between them. This split turns into the site of instability that prevents the autonomy of the pedagogical and also allows the fantastic to operate within its 'unreal' space. The site of 'split' thus becomes the site of liminality where the pedagogical and the performative partially 
share their authority, and they are reborn into a new identity: the 'authenticity' of the 'in-between'.

The power of the fantastic in the 'Wasserman' section lies purely in the strength of the storytelling. It is through the reconstruction of Wasserman's experience in the concentration camp that the inauthentic voice of Shlomo is validated in the realm to which he is forever unable to gain access. Nevertheless, such legitimation, which is purely imaginary, undermines the Zionist discourse by the two fantastic functions described by Morahg as, first, the safeguarding of the reader, which reduces only the degree of horror of the Holocaust, not its concreteness, by shielding them behind the wall of the fantastic, and, second, the recuperation of the "profound sense of unreality' which ironically presents the unrealistic nature of the world (Morahg, 1997:163-64).

The protective function emphasises the liminal attribute of the fantastic task as the performative for it decreases the actual contact with harsh reality. In a fashion similar to the resurrection of Bruno, Grossman plays with the subversive life/death fantasy in Neigel's reverse offering of Scheherazade's ${ }^{5}$ scheme of storytelling to Wasserman, who appears to be incapable of being killed by any means available in the camp; the Jewish storyteller, who loses his motivation to live, will get the chance to die if he tells Neigel a

\footnotetext{
${ }^{5}$ Scheherazade is a figure in The Thousand and One Nights who offers to tell King Shariyar one story each night in exchange for the postponement of her execution. The King turns out to be so satisfied with all her stories that he finally revokes the murder scheme he had been carrying out on the town's virgins, who were sent to sleep with him and put to death the next morning.
}

story he is satisfied with. The strangeness of Wasserman's immortality, which undermines the Nazi extermination mission, becomes further undermined by the reversed scheme of Scheherazade, which also plays the oriental, magical 'other' to familiar, Western logic. The multileveled fantasy in effect distances the audience from the dreadful 'authentic' events of the death camps, which is doubly alleviated by the shared narrative voice of Wasserman, the true witness, and Shlomo, the outsider who has been temporarily granted permission to join the Holocaust. In this way, this fantastic mode successfully brings the readers to the liminal border of the performative, safeguarding them from becoming absorbed in the unbearable horror of the genuine Holocaust.

The liminality of the fantastic not only undermines the performative by pointing out its limitations, it does the same to the pedagogical code of Holocaust by articulating its 'profound unreality'. After the death of his beloved Paula, Fried, the physician in Wasserman's story, becomes 'a consummate disciple of the ethos of survival' (Morahg, 1997:177). ${ }^{6}$ When Wasserman introduces Kazik, a baby whose life cycle spans the period of twentyfour hours, this man who is in denial of emotional attachments is touched by this innocent life that has no knowledge of the War. Fried finally realises the value of human innocence, as embodied in Kazik; he 'looked at the child with COMPASSION [q.v.] and perceived how small and weak and miserable he was, and fell sadly silent' (Grossman, 1999:355). The suicide of Kazik comes from the agony

\footnotetext{
${ }^{6}$ The 'ethos of survival' is explained by Morahg as the sole intention to survive the Holocaust no matter how inhuman it takes to live.
} 
of 'feeling bad', for he has not been with Fried, Otto, and the rest of the Children of the Heart who turn out to prevent him from knowing the truth of the War behind the Zoo's fence. The situation of Kazik then runs parallel with that of Shlomo, who was also barred from knowing the truth when he was a child. The life of Kazik thus reveals the underlying truth of Jewish parental protection; the harm of not letting the innocent understand what shapes their parents' trauma also affects the formation of their identity. This protection can produce a new trauma of unaffectionate distance between parents and their children. In this way, the Zionist pedagogical loses its absolutism of taboo, as well as its profound sacredness, and turns into a liminal entity which manifests its instability through the intrusion of the fantastic performative. Therefore the space in between the Zionist pedagogical and the fantastic performative becomes the site of new knowledge - 'authentic' in itself where the Zionist taboo has no absolute power and the fantastic always remains a distant presence.

Magical realism in Beloved works slightly differently from the fantastic in See Under: Love, in that the magical presence merges with the realism in the narrative, while the fantastic clearly detaches itself from reality and, according to Todorov, requires no explanation. ${ }^{7}$ The mode of magical realism empowers the performative in two ways: in the 'realism' of magical realism in the

\footnotetext{
7 Todorov separates unreal phenomena into three categories: the uncanny, which can be explained by scientific knowledge, the marvelous which adheres to supernatural belief, and the fantastic which is located in between the uncanny and the marvelous, and requires no explanation. For further information see Tzvetan Todorov's The Fantastic: A Structural Approach to a Literary Genre (1989).
}

Africanist context and in what Bhabha terms 'the beyond'. One of the five characteristics of magical realism proposed by Wendy Faris is that the 'descriptions detail a strong presence of the phenomenal world - this is the realism in magical realism' (1995:169). As Morrison is concerned with the silence of the authentic Black voice which comes as a result of either racial construct or the Blacks' desperate suppression of their own voice, she attempts to 'rip that veil drawn over 'proceedings too terrible to relate'" (qtd. in Grewal, 1996:157). In order to project the authentic voice of Black Americans, Morrison chooses to tell the story by incorporating into the novel the West African folklore tradition where ghosts are not unreal but truly exist as part of circular time (Grewal, 1996:160). In this way, Morrison deconstructs White domination by establishing a 'genuine' genre of Black narrative, assigning magical realism the performative task of Black 'metaphysical necessity'. Therefore, the performative presence of Beloved as a real entity in magical realism exposes the discrepancy between the signifier and the signification of the American-Africanist pedagogical. Because of Beloved, Sethe appears as a genuine human being who defines her own law of mother's love, and this ironically renders schoolteacher, the 'definer', inhuman instead. Through the sexual affair with Beloved, Paul D feels that 'the tin tobacco box' of his ascetic heart breaks open, and he becomes human once again. In this way, the image of the Blacks as slaves in a subhuman existence is revealed as mere signifier set up by the Whites, whereas the true self of the Black American lies outside that signifier. Similarly to See Under: Love, the American-Africanist pedagogical is rid of its stability and becomes uncertain as well as liminal. 
Nevertheless, the magical performative cannot claim to replace the AmericanAfricanist pedagogical totally. Although it functions as a 'metaphysical necessity' that intrudes into the 'White' tradition, magical realism is also liminal in that it still requires the White presence as its binary opposite, leaving its function traceable and, thus, rendering possible a Black narrative defined in opposition to the White's. The return of Beloved therefore mingles the two presences together to perpetuate the new space of 'the beyond', the realm where the past of oppression comes back as a 'revisionary time', and the present invites return from the past so that the experience of 'the beyond' can be represented. In 'the beyond', Bhabha explains, Sethe experiences the past embodied in her lost child as 'a kind of self-love that is also the love of the 'other': Eros and Agape together' (Bhabha, 2003:17). The past of trauma and repressed memory points out to her its 'other' - 'love' - and encourages her to maintain it in the present; this experience is situated neither in the past, which is constructed by the Whites, nor in the present, which is transformed by Beloved, but in the 'beyond', which combines the liminal spaces of these two poles in the 'in-between'. This is precisely the locus of Sethe's, as well as Morrison's, authentic voice in Black-American narrative.

\section{Conclusion: Authenticity and 'Supplementarity'}

How can the 'in-between' space claim to perpetuate authenticity? The answer may well be taken from Bhabha's notion of 'supplementarity' which corresponds with the emergence of 'authenticity' in three successive manners: first, the belatedness in discourse, second, the non-pluralistic supplement, and, third, the complementation of different systems.

Bhabha sees the emergence of cultural minority in the age of globalisation as a posterior, supplementary entity that complements the existing mainstream culture. The belatedness of successive events marks the time lag within cultural differences, which is a disjunctive temporal space that Bhabha proposes as the space for 'the discourses of emergent cultural identities' (Bhabha, 2003: 154). The belatedness of cultural difference fits into the new discourses of the Israeli and the Black American, for both are new cultural bodies that occur after the mainstream tradition. The time lag between the Jewish survivors of the Holocaust and their descendants and between the White and the Black Americans constitutes a space for the possibility of a new, authentic space where anteriority remains liminal and has no dominant power and where posterior entity comes in to supplement the existing domain, and the time-lag space becomes a supplementary space.

The supplementary strategy allows the posterior body to fill itself through the sign and symbol of the performative in order to add to the existing and self-generating pedagogical. Therefore, what comes after does not become a detached, external other to the existing cultural body that would add up to the pluralistic cultural differences. Furthermore, the posterior entity still keeps its difference, so when it comes to supplement the anterior, the shape of the discourse becomes that of a 'many as one' in which the differences are contained in a single space. This is similar to Walter Benjamin's theory of translation which claims that translation, with the different language system, grants the original text its afterlife. This afterlife also embodies the 
spirit of 'pure language', as the language used in translation complements what is lacking in the original language system, making the translation come closer to a more 'perfect' language — 'a pure language'. It is also the different language system that renders the translation pluralistic in itself; this 'many as one' is an 'authenticity' precisely because it does not copy exactly from the original but supplements it with its own unique system. Therefore, See Under: Love is an authentic work of the Holocaust, for it succeeds in supplementing the Zionist discourse with its very own system: the fantastic performative. Likewise, Beloved proves an authentic voice because it does not suppress the Whites' voice but supplements it with its system of African-American 'metaphysical necessity': the magicalrealism mode. Both are authentic as manyas-one, unified discourses which contain time-lag differences.

It is precisely the interstitial space between the pedagogical and the performative, together with the time lag between the anterior and posterior cultural bodies that generate the site for the many-as-one authenticity. In a way, reading trauma and repressed memory through Bhabha lessens the tension of authenticity in the Zionist and American-Africanist discourses and gives a passionate way to read modern fictions by counting on their 'belated' merit and also by being aware of the transgressive and uncertain nature of the modern world.

\section{References}

Bhabha, Homi. 2003. The Location of Culture. London: Routledge.

Brown, Russell. E. 1990. Bruno Schulz and World Literature. The Slavic and East European Journal 34:224-246.
Des Pres, Terrence. 1988. Holocaust Laughter? In Writing and the Holocaust, ed. by Berel Lang. New York: Holmes \& Meier.

Faris, Wendy B. 1995. Scheherazade's Children: Magical Realism and Postmodern Fiction. In Magical Realism: Theory, History, Community, ed. by Lois Zamora and Wendy B. Faris. Durham: Duke University Press.

Grewal, Gurleen. 1996. Memory and the Matrix of History: The Poetics of Loss and Recovery in Joy Kogawa's Obasan and Toni Morrison's Beloved. In Memory and Cultural Politics, ed. by Amrijit Singh, Joseph Skerrett, Jr., and Robert Hogan. Ann Arbor: Northeastern University Press.

Grossman, David. 1999. See Under: Love. London: Vintage.

Jackson, Rosemary. 1981. Fantasy: The Literature of Subversion. New York: Methuen.

Morahg, Gilead. 1997. Breaking Silence: Israel's Fantastic Fiction of the Holocaust. In The Boom in Contemporary Israeli Fiction, ed. by Alan Mintz. Hanover: Brandeis University Press.

Morahg, Gilead. 1999. Israel's New Literature of the Holocaust: The Case of David Grossman's See Under: Love. Modern Fiction Studies 45:457-79. 
MANUSYA: Journal of Humanities (Special Issue No.10 2005)

Morrison, Toni. 1992. Playing in the Dark:

Whiteness and the Literary

Imagination. Cambridge: Harvard University Press.

Morrison, Toni. 1987. Beloved. London:

Vintage.

Todorov, Tzvetan. 1989. The Fantastic: A Structural Approach to a Literary Genre. Translated by Richard Howard. Ithaca: Cornell University Press. 